\title{
Anharmonic Vibrational Spectra of Acetylacetone
}

\author{
I. MATANOVIĆ, N. DOŠLIĆ \\ Department of Physical Chemistry, R. Bošković Institute, Bijenička 54, 10000 Zagreb, Croatia
}

Received 22 November 2004; accepted 16 February 2005

Published online 12 December 2005 in Wiley InterScience (www.interscience.wiley.com).

DOI 10.1002/qua.20894

\begin{abstract}
The spectroscopic proprieties of two energetically close conformers of acetylacetone have been investigated using density functional methods. The calculated anharmonic frequencies are in very satisfactory agreement with experimental data. The low height of the conversion barrier explains why the signature of both conformers can be found in the vibrational spectrum. (c) 2005 Wiley Periodicals, Inc. Int J Quantum Chem 106: 1367-1374, 2006
\end{abstract}

Key words: density functional computation; harmonic approximation; anharmonic corrections; infrared spectrum; intramolecular proton transfer

\section{Introduction}

$\mathbf{S}$ tudies of the enol form of $\beta$-diketones can provide an understanding of the structure and dynamics of intramolecular hydrogen bonds [1,2]. As the smallest molecules exhibiting intramolecular $\mathrm{H}$-bonding, they provide a solid foundation for the study of $\mathrm{H}$-bonding in complex systems.

The intramolecular $\mathrm{H}$-bond of $\beta$-diketones is characterized by highly complex vibrational dynamics: proton transfer (PT) motion along the double minimum potential, coupling of different normal modes, and Fermi resonance [3-6]. Consequently,

Correspondence to: N. Došlić; e-mail: nadja.doslic@irb.hr

Contract grant sponsor: Croatian Ministry of Science and Technology.

Contract grant number: 0098033.

Contract grant sponsor: Humboldt Foundation. the (IR) spectra show a broad, red-shifted OH-stretch absorption band. The structure of the bend encodes information on the pathways and time scales of the vibrational energy redistribution processes. Experimental observation of the $\mathrm{OH}$-stretching dynamics, however, became possible only recently with the development of intense femtosecond lasers in the IR domain $[7,8]$. Turning to malonaldehyde (MA), the proton transfer model system par excellence, information on the $\mathrm{OH}$-stretching motion is hardly accessible due to the very low intensity of the mode $[9,10]$. In contrast, the IR spectrum of acetylacetone (ACAC) is dominated by a strongly broadened $\mathrm{OH}$-stretch band [11-13]. The band is located at $2000-3400 \mathrm{~cm}^{-1}$, with a maximum at $\approx 2800 \mathrm{~cm}^{-1}$. Upon deuteration of the bridging proton, the band center shifts to $2030 \mathrm{~cm}^{-1}$, and the bandwidth is reduced to $\approx 200 \mathrm{~cm}^{-1}$. Using mixed quantum classical density matrix evolution theory, Mavri and Grdadolnik $[13,14]$ could explain the bulk of these 


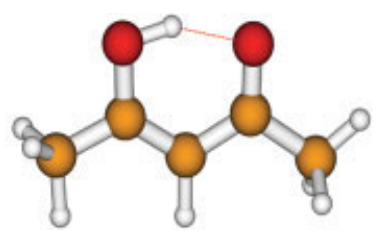

SYN

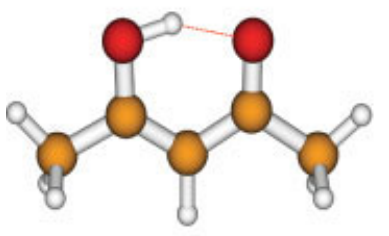

TS1

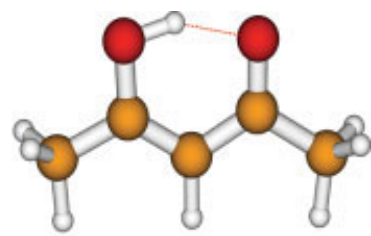

TS2

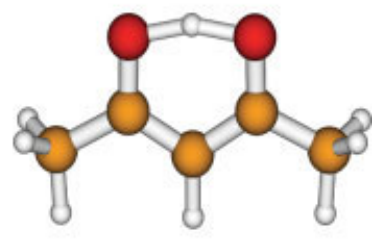

TS3

FIGURE 1. Relevant ACAC structures. Top: Global minimum structure (SYN), and transition state for rotation of the distal methyl group (TS2). Bottom: Transition states for rotation of the proximal methyl group (TS1) and for the $\mathrm{PT}$ reaction (TS3).

effects. Because of the simplified two-state empirical valence form of the potential, however, they could not provide any insight into the mode coupling dynamics.

Currently, the most accurate ab initio vibrational frequency calculation has been reported by Tayyary and Milani-nejad [15], who provide a comprehensive overview of experimental results. Besides the notorious anharmonicity of the $\mathrm{OH}$-stretch band, the vibrational spectrum of ACAC displays intriguing features in the bending modes of the hydrogen bond. A broad, intense line that splits at low temperature into three components is observed at $\approx 1630 \mathrm{~cm}^{-1}$ [16]. The structure of the line has been explained by the presence of two rapidly interconverting forms of the enolic ACAC $[15,16]$. Still, in our opinion, a conclusive assignment is missing, since the discrepancies between the harmonic and the observed frequencies are close to $90 \mathrm{~cm}^{-1}$. In the present study, we calculate the anharmonic vibrational spectrum of two, energetically close, conformers of ACAC. By going beyond the harmonic approximation, we will be able not only to improve the agreement with the experiment, but also to understand the nature of the vibrational modes coupling that lead to anharmonicities in the ACAC spectrum.

This study is organized as follows. The computational methods are briefly described in Section 2. In Section 3, the most important stationary points of the enolic ACAC are analyzed first, and then the

results of the anharmonic frequency calculations are presented. The study is summarized in Section 4.

\section{Computational Methods}

Second-order Møller-Plesset perturbation theory (MP2) and density functional theory (DFT) with the B1LYP [17] exchange-correlation functional have been used to optimize the geometries of the stationary points of interest and to determine the relative energies of the these points. All calculations were performed using the Gaussian 03 [18] and Gamess [19] quantum chemical software packages. Harmonic vibrational analysis have been performed to characterize each point as a minimum, a transition state, or a higher-order saddle point. The anharmonic frequencies have been calculated by the second-order perturbative treatment used by Barone and Manichino [20,21]. The method is implemented in the Gaussian 03 suite of programs [18].

\section{Results and Discussion}

\subsection{ANALYSIS OF THE STATIONARY POINTS}

In the gas phase, the energetically preferred structure of ACAC is the syn-enol isomer with $C_{\mathrm{s}}$ pointgroup symmetry (SYN)[22-24]. Structures TS1, TS2, and TS3, shown in Figure 1, are first-order transition structures for the two internal rotations of the methyl groups, and for the intramolecular PT reaction between two equivalent syn-enol isomers, respectively. Since the geometric and energetic properties of the these stationary points have been investigated in Ref. [24], we summarize the most salient results. The TS1 structure is $1.45(1.32) \mathrm{kcal} \mathrm{mol}^{-1}$ above the minimum energy structure at the $\mathrm{MP} 2(\mathrm{FC}) /$ 6-311G $(d, p)$ [B1LYP/6-311G $(d, p)$ ] level of theory, while TS2 is only $0.25(0.13) \mathrm{kcal} \mathrm{mol}^{-1}$ above SYN at MP2(FC)/6-311G $(d, p)$ [B1LYP/6-311G $(d, p)]$. The
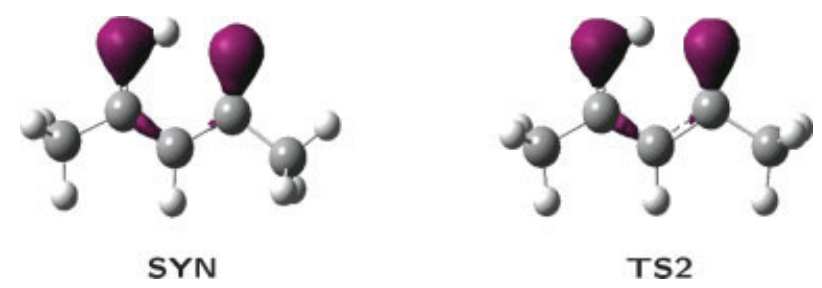

FIGURE 2. Electron density distributions in SYN and TS2 conformers of ACAC at an isosurface value of $0.3 e \AA^{-3}$. 
TABLE I

Vibrational frequencies in $\mathrm{cm}^{-1}$ of SYN-ACAC conformer at MP2/6-311G $(d, p)$ and B1LYP/6-311G(d,p) levels of theory.*

\begin{tabular}{|c|c|c|c|c|c|c|c|}
\hline & $\operatorname{Exp}(s)$ & Int. & MP2(h) & B1LYP(h) & Int. & B1LYP(a) & Mode \\
\hline 1 & - & - & 3258 & 3217 & 2 & 3101 & $v \mathrm{CH}_{\text {olefinic }}$ \\
\hline 2 & 2800 & $\mathrm{br}$ & 3192 & 3160 & 85 & 2766 & $v \mathrm{OH}$ \\
\hline 3 & 3017 & 10 & 3206 & 3151 & 2 & 2991 & $v_{a} \mathrm{CH}_{3}$ \\
\hline 4 & 3017 & 10 & 3202 & 3144 & 19 & 2935 & $v_{a} \mathrm{CH}_{3}$ \\
\hline 5 & 2976 & 6 & 3166 & 3101 & 3 & 2961 & $v_{a} \mathrm{CH}_{3}$ \\
\hline 6 & 2976 & 6 & 3164 & 3098 & 3 & 2988 & $v_{a} \mathrm{CH}_{3}$ \\
\hline 7 & 2941 & 7 & 3085 & 3048 & 2 & 2944 & $v_{s} \mathrm{CH}_{3}$ \\
\hline 8 & 2941 & 7 & 3080 & 3043 & 1 & 2952 & $v_{s} \mathrm{CH}_{3}$ \\
\hline 9 & 1642 & 19 & 1716 & 1700 & 96 & 1650 & $v_{a} \mathrm{C}=\mathrm{C}-\mathrm{C}=\mathrm{O}+\delta \mathrm{OH}$ \\
\hline 10 & 1624 & 77 & 1687 & 1660 & 100 & 1625 & $v \mathrm{C}=\mathrm{O}+\delta \mathrm{OH}$ \\
\hline 11 & 1464 & 10 & 1512 & 1501 & 14 & 1464 & $\delta_{a} \mathrm{CH}_{3}$ \\
\hline 12 & - & - & 1494 & 1485 & 2 & 1471 & $\delta_{a} \mathrm{CH}_{3}$ \\
\hline 13 & - & - & 1491 & 1480 & 3 & 1460 & $\delta_{a} \mathrm{CH}_{3}$ \\
\hline 14 & - & - & 1488 & 1479 & 3 & 1438 & $\delta_{a} \mathrm{CH}_{3}$ \\
\hline 15 & 1427 & 17 & 1478 & 1468 & 47 & 1443 & $v_{a} \mathrm{CC}=\mathrm{CO}+\delta \mathrm{CH}+\delta \mathrm{OH}+v \mathrm{C}-\mathrm{CH}_{3}$ \\
\hline 16 & - & - & 1416 & 1424 & 11 & 1380 & $\delta_{s} \mathrm{CH}_{3}+\delta \mathrm{OH}$ \\
\hline 17 & - & - & 1443 & 1402 & 29 & 1345 & $\delta \mathrm{OH}+v \mathrm{C}=\mathrm{O}+v_{s} \mathrm{C}-\mathrm{C}=\mathrm{C}-\mathrm{O}$ \\
\hline 18 & 1365 & 10 & 1397 & 1394 & 11 & 1369 & $\delta_{s} \mathrm{CH}_{3}+\delta \mathrm{OH}$ \\
\hline 19 & 1250 & 17 & 1292 & 1275 & 46 & 1243 & $v_{s} \mathrm{C}-\mathrm{C}=\mathrm{C}+\delta \mathrm{OH}+v \mathrm{C}-\mathrm{CH}_{3}$ \\
\hline 20 & 1171 & 6 & 1198 & 1199 & 5 & 1183 & $\delta \mathrm{CH}_{\text {olefinic }}$ \\
\hline 21 & - & - & 1069 & 1072 & 1 & 1048 & $\pi \mathrm{CH}_{3}$ \\
\hline 22 & - & - & 1048 & 1052 & 3 & 1043 & $\pi \mathrm{CH}_{3}$ \\
\hline 23 & 1025 & 1 & 1043 & 1041 & 3 & 1023 & $\rho \mathrm{CH}_{3}$ \\
\hline 24 & 1000 & 4 & 1018 & 1013 & 4 & 1017 & $\rho \mathrm{CH}_{3}$ \\
\hline 25 & 952 & 10 & 962 & 968 & 25 & 954 & $\gamma \mathrm{OH}$ \\
\hline 26 & - & - & 951 & 947 & 1 & 937 & $\delta \mathrm{C}-\mathrm{C}=\mathrm{C}+v \mathrm{C}-\mathrm{C}+\rho \mathrm{CH}_{3}$ \\
\hline 27 & 913 & 9 & 929 & 921 & 11 & 922 & $v \mathrm{C}-\mathrm{CH}_{3}+v \mathrm{C}-\mathrm{O}$ \\
\hline 28 & 768 & 40 & 777 & 799 & 11 & 766 & $\gamma \mathrm{CH}_{\text {olefinic }}$ \\
\hline 29 & - & - & 627 & 653 & - & 653 & $\Gamma_{\text {ring }}$ \\
\hline 30 & 636 & 9 & 655 & 650 & 4 & 634 & $\Delta_{\text {ring }}$ \\
\hline 31 & - & - & 537 & 556 & - & 566 & $\Gamma_{\text {ring }}$ \\
\hline 32 & 508 & 20 & 509 & 512 & 4 & 513 & $\Delta_{\text {ring }}$ \\
\hline 33 & 397 & $\mathrm{~s}$ & 393 & 398 & 1 & 412 & $\Delta_{\text {ring }}$ \\
\hline 34 & 362 & $s$ & 365 & 371 & 2 & 368 & $v 0 \ldots 0$ \\
\hline 35 & 210 & $w$ & 225 & 230 & 1 & 238 & $\Gamma_{\text {ring }}+\gamma \mathrm{C}-\mathrm{CH}_{3}$ \\
\hline 36 & - & - & 183 & 182 & - & 177 & $\Gamma_{\text {ring }}+\tau \mathrm{CH}_{3}$ \\
\hline 37 & - & - & 150 & 154 & - & 152 & $\tau \mathrm{CH}_{3}$ \\
\hline 38 & 120 & w & 113 & 121 & 1 & 125 & $\tau \mathrm{CH}_{3}$ \\
\hline 39 & - & - & 51 & 23 & - & Not converged & $\tau \mathrm{CH}_{3}$ \\
\hline
\end{tabular}

*Exp. data taken from Ref. [15].

s, gas; h, harmonic; a, anharmonic.

energy of the H-bond, i.e., the energy difference between the anti and syn-enol forms is $15.4 \mathrm{kcal} \mathrm{mol}^{-1}$ at MP2(FC)/6-311G $(d, p)$ level of theory.

A very interesting aspect of the PT reaction in ACAC is the coupling of two large-amplitude motions: the rotation of the distal methyl group and the double well motion of the bridging $\mathrm{H}$-atom [25]. Inspection of Figure 1 indeed reveals a different orientation of the methyl groups at a minimum and at the transition state. The calculation of the reaction path for the PT reaction given in Ref. [24] does not support a hypothesis of concerted motion. Instead, our analysis suggests that the PT reaction is triggered only after the methyl groups reaches an eclipsed conformation. To investigate this issue more thoroughly, in Figure 2 we show a contour plot of the correlated 
TABLE II

B1LYP/6-311G(d,p) vibrational frequencies in $\mathrm{cm}^{-1}$ of d2-ACAC SYN conformer.

\begin{tabular}{|c|c|c|c|c|c|c|}
\hline & $\operatorname{Exp}(s)$ & Int. & B1LYP(h) & Int. & B1LYP(a) & Mode \\
\hline 1 & 3018 & $w$ & 3152 & 3 & 3015 & $v_{a} \mathrm{CH}_{3}$ (in plane) \\
\hline 2 & 3018 & & 3147 & 3 & 3000 & $v_{a} \mathrm{CH}_{3}$ (in plane) \\
\hline 3 & 2970 & $w$ & 3101 & 2 & 2961 & $v_{a} \mathrm{CH}_{3}$ (out of plane) \\
\hline 4 & 2970 & & 3098 & 3 & 2988 & $v_{a} \mathrm{CH}_{3}$ (out of plane) \\
\hline 5 & 2940 & $w$ & 3048 & 2 & 2943 & $v_{s} \mathrm{CH}_{3}$ \\
\hline 6 & 2940 & & 3043 & 1 & 2951 & $v_{s} \mathrm{CH}_{3}$ \\
\hline 7 & 2300 & $w$ & 2378 & 1 & 2299 & $v \mathrm{CD}_{\text {olefinic }}$ \\
\hline 8 & 2027 & & 2306 & 54 & 2027 & $v \mathrm{OD}$ \\
\hline 9 & 1633 & vs & 1689 & 63 & 1645 & $v_{a} \mathrm{C}=\mathrm{C}-\mathrm{C}=\mathrm{O}$ \\
\hline 10 & 1544 & vs & 1582 & 100 & 1531 & $v_{s} \mathrm{C}=\mathrm{C}-\mathrm{C}=\mathrm{O}+\delta \mathrm{OD}$ \\
\hline 11 & 1448 & & 1488 & 21 & 1447 & $\delta_{a} \mathrm{CH}_{3}$ (in plane) \\
\hline 12 & - & & 1485 & 2 & 1472 & $\delta_{a} \mathrm{CH}_{3}$ (out of plane) \\
\hline 13 & - & & 1479 & 2 & 1443 & $\delta_{a} \mathrm{CH}_{3}$ (out of plane) \\
\hline 14 & 1448 & $\mathrm{~s}$ & 1474 & 9 & 1462 & $\delta_{a} \mathrm{CH}_{3}$ (in plane) \\
\hline 15 & 1408 & br & 1433 & 9 & 1399 & $v_{a} \mathrm{C}-\mathrm{C}=\mathrm{C}-\mathrm{O}$ \\
\hline 16 & 1365 & $\mathrm{~s}$ & 1411 & 5 & 1383 & $\delta_{s} \mathrm{CH}_{3}$ \\
\hline 17 & 1365 & & 1391 & 13 & 1372 & $\delta_{s} \mathrm{CH}_{3}$ \\
\hline 18 & 1273 & vs & 1308 & 32 & 1274 & $v_{s} \mathrm{C}-\mathrm{C}=\mathrm{C}-\mathrm{O}$ \\
\hline 19 & 1082 & $\mathrm{~m}$ & 1128 & 15 & 1102 & $\delta \mathrm{OD}+v \mathrm{C}=\mathrm{C}+\rho \mathrm{CH}_{3}$ \\
\hline 20 & - & & 1071 & 1 & 1047 & $\pi \mathrm{CH}_{3}$ \\
\hline 21 & 1025 & $\mathrm{~m}$ & 1052 & 2 & 1043 & $\pi \mathrm{CH}_{3}$ \\
\hline 22 & 1025 & & 1051 & 10 & 1038 & $\rho \mathrm{CH}_{3}+\delta \mathrm{OD}$ \\
\hline 23 & - & & 1013 & 2 & 1013 & $\rho \mathrm{CH}_{3}$ \\
\hline 24 & 936 & $\mathrm{~m}$ & 949 & 6 & 940 & $v \mathrm{C}-\mathrm{CH}_{3}+\rho \mathrm{CH}_{3}+\delta \mathrm{CD}_{\text {olefinic }}$ \\
\hline 25 & 880 & $w$ & 893 & 4 & 891 & $v \mathrm{C}-\mathrm{O}+\delta \mathrm{C}-\mathrm{C}=\mathrm{C}+\rho \mathrm{CH}_{3}$ \\
\hline 26 & - & & 850 & - & 843 & $\delta \mathrm{CD}_{\text {olefinic }}$ \\
\hline 27 & 707 & $\mathrm{~ms}$ & 730 & 12 & 724 & $\gamma \mathrm{OD}$ \\
\hline 28 & & & 654 & - & 640 & $\Gamma_{\text {ring }}$ \\
\hline 29 & 631 & $\mathrm{~m}$ & 644 & 3 & 631 & $\Delta_{\text {ring }}$ \\
\hline 30 & - & & 573 & 5 & 565 & $\gamma \mathrm{CD}_{\text {olefinic }}$ \\
\hline 31 & - & & 554 & - & 563 & $\Gamma_{\text {ring }}$ \\
\hline 32 & 498 & $\mathrm{~m}$ & 503 & 3 & 504 & $\Delta_{\text {ring }}$ \\
\hline 33 & 397 & $\mathrm{~s}$ & 391 & 1 & 403 & $\Delta_{\text {ring }}$ \\
\hline 34 & 362 & $\mathrm{~s}$ & 364 & 2 & 364 & $v O \cdots O$ \\
\hline 35 & 220 & $\mathrm{br}$ & 226 & 1 & 234 & $v \mathrm{O} \cdots \mathrm{O}+\delta \mathrm{C}-\mathrm{CH}_{3}$ \\
\hline 36 & - & & 180 & - & 175 & $\Gamma_{\text {ring }}$ \\
\hline 37 & - & & 153 & - & 149 & $\Gamma_{\text {ring }}$ \\
\hline 38 & 120 & br & 119 & 1 & 126 & $\tau \mathrm{CH}_{3}$ \\
\hline 39 & - & & 23 & - & Not converged & $\tau \mathrm{CH}_{3}$ \\
\hline
\end{tabular}

electron density in the SYN and TS2 structures [26]. Apparently, the charge density in the $\mathrm{O} \cdots \mathrm{H} \cdots \mathrm{O}$ region has been affected only in a limited extent by the rotation of the methyl group. In contrast, a synchronized mechanism would imply a large displacement of charges in the PT moiety.

\subsection{VIBRATIONAL SPECTRA}

Table I compiles the harmonic frequencies of ACAC at the MP2/6-311G $(d, p)$ and B1LYP/6-311G $(d, p)$ levels of theory along with the anharmonic frequencies and observed gas-phase transitions. To facilitate comparison with previous studies, we retain the normal-modes interpretation described in Ref. [15]. On average, the deviation from experiment is $0.96 \%$. Although the agreement between computed anharmonic frequencies and experiment is very good, a number of transitions deserve further discussion.

As expected, the largest anharmonicity is observed for the $\mathrm{OH}$-stretching vibration. The $\mathrm{OH}$-stretch 
TABLE III

B1LYP/6-311G $(d, p)$ vibrational frequencies in $\mathrm{cm}^{-1}$ of d6-ACAC SYN conformer.

\begin{tabular}{|c|c|c|c|c|c|c|}
\hline & $\operatorname{Exp}(s)$ & Int. & B1LYP(h) & Int. & B1LYP(a) & Mode \\
\hline 1 & 3098 & - & 3217 & 1 & 3090 & $v \mathrm{CH}_{\text {olefinic }}$ \\
\hline 2 & 2761 & 4 & 3156 & 95 & 2680 & $v \mathrm{OH}$ \\
\hline 3 & 2265 & 2 & 2337 & 2 & 2260 & $v_{a} \mathrm{CD}_{3}$ (in plane) \\
\hline 4 & 2265 & 2 & 2332 & 2 & 2250 & $v_{a} \mathrm{CD}_{3}$ (in plane) \\
\hline 5 & - & - & 2294 & 2 & 2220 & $v_{a} \mathrm{CD}_{3}$ (out of plane) \\
\hline 6 & - & - & 2292 & 2 & 2229 & $v_{a} \mathrm{CD}_{3}$ (out of plane) \\
\hline 7 & 2103 & - & 2192 & 1 & 2108 & $v_{s} \mathrm{CD}_{3}$ \\
\hline 8 & 2103 & - & 2187 & - & 2182 & $v_{s} \mathrm{CD}_{3}$ \\
\hline 9 & 1628 & 100 & 1692 & 100 & 1645 & $v_{a} \mathrm{C}=\mathrm{C}-\mathrm{C}=\mathrm{O}+\delta \mathrm{OH}$ \\
\hline 10 & 1606 & 100 & 1654 & 100 & 1611 & $v \mathrm{C}=\mathrm{O}+\delta \mathrm{OH}$ \\
\hline 11 & 1446 & 36 & 1474 & 48 & 1447 & $v_{a} \mathrm{C}=\mathrm{C}-\mathrm{C}=\mathrm{O}+\delta \mathrm{OH}+\delta_{s} \mathrm{CH}$ \\
\hline 12 & 1294 & 15 & 1406 & 32 & 1326 & $v_{s} \mathrm{C}=\mathrm{C}-\mathrm{C}=\mathrm{O}+\delta \mathrm{OH}+v \mathrm{C}-\mathrm{O}$ \\
\hline 13 & 1265 & 59 & 1287 & 56 & 1260 & $v_{s} \mathrm{C}-\mathrm{CD}_{3}+v_{s} \mathrm{C}-\mathrm{C}=\mathrm{C}+\delta \mathrm{OH}$ \\
\hline 14 & 1185 & 21 & 1209 & 14 & 1194 & $\delta \mathrm{CH}_{\text {olefinic }}$ \\
\hline 15 & 1075 & 2 & 1107 & 2 & 1090 & $\delta \mathrm{CH}_{\text {olefinic }}+\delta_{a} \mathrm{CD}_{3}$ \\
\hline 16 & 1051 & - & 1086 & 1 & 1073 & $\delta_{a} \mathrm{CD}_{3}$ \\
\hline 17 & 1051 & - & 1071 & 1 & 1058 & $\delta_{s} \mathrm{CD}_{3}$ \\
\hline 18 & - & - & 1068 & 4 & 1044 & $\delta_{a} \mathrm{CD}_{3}$ \\
\hline 19 & - & - & 1066 & 2 & 1047 & $\delta_{a} \mathrm{CD}_{3}$ \\
\hline 20 & 1036 & 2 & 1059 & 2 & 1050 & $\delta_{a} \mathrm{CD}_{3}$ \\
\hline 21 & 952 & 3 & 970 & 28 & 953 & $\gamma \mathrm{OH}$ \\
\hline 22 & 931 & 4 & 959 & 1 & 946 & $v \mathrm{C}-\mathrm{O}+\delta \mathrm{C}-\mathrm{C}=\mathrm{C}+\delta \mathrm{OH}$ \\
\hline 23 & - & - & 925 & 1 & 911 & $\rho \mathrm{CD}_{3}$ \\
\hline 24 & 914 & 1 & 912 & 1 & 898 & $\rho \mathrm{CD}_{3}$ \\
\hline 25 & 904 & 3 & 889 & 1 & 875 & $v_{a} \mathrm{C}-\mathrm{CD}_{3}$ \\
\hline 26 & 812 & 5 & 828 & 3 & 817 & $\rho \mathrm{CD}_{3}$ \\
\hline 27 & 803 & 10 & 792 & 9 & 797 & $\rho \mathrm{CD}_{3}$ \\
\hline 28 & 763 & 3 & 793 & 4 & 759 & $\gamma \mathrm{CH}_{\text {olefinic }}$ \\
\hline 29 & 585 & 5 & 592 & 4 & 586 & $\Delta_{\text {ring }}$ \\
\hline 30 & - & - & 573 & - & 574 & $\Gamma_{\text {ring }}+\rho \mathrm{CD}_{3}$ \\
\hline 31 & 492 & 3 & 489 & - & 495 & $\Gamma_{\text {ring }}+\rho \mathrm{CD}_{3}$ \\
\hline 32 & 477 & 10 & 480 & 4 & 480 & $\Delta_{\text {ring }}+\rho \mathrm{CD}_{3}$ \\
\hline 33 & 360 & & 361 & 1 & 372 & $\Delta_{\text {ring }}+\rho \mathrm{CD}_{3}$ \\
\hline 34 & 337 & & 350 & 2 & 341 & $v 0 \ldots O$ \\
\hline 35 & 212 & & 208 & 1 & 213 & $\Delta_{\text {ring }}+\rho \mathrm{CD}_{3}$ \\
\hline 36 & - & & 167 & - & 166 & $\Gamma_{\text {ring }}+\rho \mathrm{CD}_{3}$ \\
\hline 37 & - & & 136 & - & 140 & $\Gamma_{\text {ring }}+\rho \mathrm{CD}_{3}$ \\
\hline 38 & - & & 95 & - & 87 & $\tau \mathrm{CD}_{3}$ \\
\hline 39 & - & & 17 & - & Not converged & $\tau \mathrm{CD}_{3}$ \\
\hline
\end{tabular}

fundamental is at $2766 \mathrm{~cm}^{-1}$, in very good agreement with the experiment. Compared with its harmonic value, the transition is red-shifted by $393 \mathrm{~cm}^{-1}$. Upon deuteration of the bridging $\mathrm{H}$-atom (d2-ACAC, Table II), the $v_{O D}$ frequencies shift to $2027 \mathrm{~cm}^{-1}$, again in agreement with the experiment, while deuteration of the two methyl groups (d6-ACAC, Table III) yield $v_{\mathrm{OH}}=2679 \mathrm{~cm}^{-1}, \sim 80 \mathrm{~cm}^{-1}$ above the center of the experimental band. For the deuterated compounds, the average deviation from the experiment is $0.82 \%$ (d2-ACAC) and $0.86 \%$ (d6-ACAC).
The larger deviation from the experiment in the d6-ACAC $v_{\mathrm{OH}}$ frequency may be due to the inclusion of only two Fermi resonance interactions (see Refs. [21] and [27]), with $v_{7}+v_{22}$ and $v_{9}+v_{11}$. In contrast, the $\mathrm{OH}$-stretch band has a bandwidth of few hundred $\mathrm{cm}^{-1}$, and the experimental assignment of $2761 \mathrm{~cm}^{-1}$ is only approximative. Also, Tables I-IV present harmonic IR intensities. The value of a harmonic intensities are comperable to the experimental ones, with a larger discrepancy seen only in the case of a $v_{\mathrm{OH}} \mathrm{d} 6$-ACAC fundamental again. 
TABLE IV

B1LYP/6-311G(d,p) vibrational frequencies $\mathrm{cm}^{-1}$ of TS2-ACAC conformer.

\begin{tabular}{|c|c|c|c|c|}
\hline & B1LYP(h) & Int. & B1LYP(a) & Mode \\
\hline 1 & 3225 & 1 & 3098 & $v \mathrm{CH}_{\text {olefinic }}$ \\
\hline 2 & 3148 & 4 & 2997 & $v_{a} \mathrm{CH}_{3}$ \\
\hline 3 & 3137 & 7 & 2987 & $v_{a} \mathrm{CH}_{3}$ \\
\hline 4 & 3112 & 2 & 2984 & $v_{a} \mathrm{CH}_{3}$ \\
\hline 5 & 3101 & 2 & 2961 & $v_{a} \mathrm{CH}_{3}$ \\
\hline 6 & 3091 & 90 & 2487 & $v \mathrm{OH}$ \\
\hline 7 & 3051 & 1 & 2951 & $v_{s} \mathrm{CH}_{3}$ \\
\hline 8 & 3048 & 1 & 2943 & $v_{s} \mathrm{CH}_{3}$ \\
\hline 9 & 1691 & 100 & 1644 & $v_{a} \mathrm{C}=\mathrm{C}-\mathrm{C}=\mathrm{O}+\delta \mathrm{OH}$ \\
\hline 10 & 1656 & 80 & 1628 & $v \mathrm{C}=\mathrm{O}+\delta \mathrm{OH}$ \\
\hline 11 & 1506 & 15 & 1466 & $\delta_{a} \mathrm{CH}_{3}$ \\
\hline 12 & 1492 & 1 & 1447 & $\delta_{a} \mathrm{CH}_{3}$ \\
\hline 13 & 1482 & 3 & 1443 & $\delta_{a} \mathrm{CH}_{3}$ \\
\hline 14 & 1479 & 2 & 1438 & $\delta_{a} \mathrm{CH}_{3}$ \\
\hline 15 & 1470 & 44 & 1437 & $v_{a} \mathrm{C}-\mathrm{C}=\mathrm{C}-\mathrm{O}+\delta \mathrm{CH}+\delta \mathrm{OH}+v \mathrm{C}-\mathrm{CH}_{3}$ \\
\hline 16 & 1421 & 5 & 1380 & $\delta_{s} \mathrm{CH}_{3}+\delta \mathrm{OH}$ \\
\hline 17 & 1402 & 9 & 1371 & $\delta_{s} \mathrm{CH}_{3}+\delta \mathrm{OH}$ \\
\hline 18 & 1393 & 37 & 1318 & $\delta \mathrm{OH}+v \mathrm{C}=\mathrm{O}+v_{s} \mathrm{C}-\mathrm{C}=\mathrm{C}-\mathrm{O}$ \\
\hline 19 & 1273 & 43 & 1242 & $v_{s} \mathrm{C}-\mathrm{C}=\mathrm{C}+\delta \mathrm{OH}+v \mathrm{C}-\mathrm{CH}_{3}$ \\
\hline 20 & 1199 & 7 & 1178 & $\delta \mathrm{CH}_{\text {olefinic }}$ \\
\hline 21 & 1073 & 1 & 1048 & $\pi \mathrm{CH}_{3}$ \\
\hline 22 & 1053 & 5 & 1031 & $\pi \mathrm{CH}_{3}$ \\
\hline 23 & 1040 & 2 & 1022 & $\rho \mathrm{CH}_{3}$ \\
\hline 24 & 1026 & 3 & 1008 & $\rho \mathrm{CH}_{3}$ \\
\hline 25 & 987 & 22 & 965 & $\gamma \mathrm{OH}$ \\
\hline 26 & 953 & 2 & 939 & $\delta \mathrm{C}-\mathrm{C}=\mathrm{C}+v \mathrm{C}-\mathrm{C}+\rho \mathrm{CH}_{3}$ \\
\hline 27 & 933 & 4 & 916 & $v \mathrm{C}-\mathrm{CH}_{3}+v \mathrm{C}-\mathrm{O}$ \\
\hline 28 & 799 & 9 & 758 & $\gamma \mathrm{CH}_{\text {olefinic }}$ \\
\hline 29 & 665 & - & 657 & $\Gamma_{\text {ring }}$ \\
\hline 30 & 641 & 4 & 635 & $\Delta_{\text {ring }}$ \\
\hline 31 & 562 & - & 561 & $\Gamma_{\text {ring }}$ \\
\hline 32 & 510 & 4 & 511 & $\Delta_{\text {ring }}$ \\
\hline 33 & 406 & 1 & 405 & $\Delta_{\text {ring }}$ \\
\hline 34 & 373 & 2 & 363 & $v 0 \cdots O$ \\
\hline 35 & 235 & 1 & 224 & $\Gamma_{\text {ring }}+\gamma \mathrm{C}-\mathrm{CH}_{3}$ \\
\hline 36 & 182 & - & 176 & $\Gamma_{\text {ring }}+\tau \mathrm{CH}_{3}$ \\
\hline 37 & 153 & - & 146 & $\tau \mathrm{CH}_{3}$ \\
\hline 38 & 122 & - & 106 & $\tau \mathrm{CH}_{3}$ \\
\hline 39 & $54.492 i$ & - & $32.501 i$ & $\tau \mathrm{CH}_{3}$ \\
\hline
\end{tabular}

A nonperturbative description of the $v_{\mathrm{OH}}$ band requires knowledge of the multidimensional potential energy surface (PES). This topic is beyond scope of the present study. However, two-dimensional cuts of the PES already provide insight into the mode-mixing dynamics. Besides the low-frequency modes modifying the inter-oxygen distance, the $\mathrm{OH}$-stretching vibration appears to be strongly coupled to the $\mathrm{CH}_{3}$ torsion modes. To gain a better understanding of these effects, we have calculated the anharmonic vibrational frequencies of the TS2 rotamer (see Fig. 1). The results are given in Table IV. In TS2, the OH-stretch fundamental is located at $2487 \mathrm{~cm}^{-1}$. Compared with the anharmonic frequency of the SYN structure, the mode is red-shifted by $280 \mathrm{~cm}^{-1}$. This large difference suggests that the extreme broadness of the $v_{\mathrm{OH}}$ band in the IR spectrum of ACAC may be caused by the coexistence of the SYN and TS2 structures the gas phase.

Next we focus on the $1000-1700 \mathrm{~cm}^{-1}$ region, where the harmonic analysis predicts five modes made up from $\mathrm{OH}$ in-plane bending and $\mathrm{C}=\mathrm{O}$, 
$\mathrm{C}-\mathrm{O}, \mathrm{C}=\mathrm{C}$, and $\mathrm{C}-\mathrm{C}$ stretching. Two transitions are observed in the deconvoluted spectrum of ACAC in the $\mathrm{C}=\mathrm{O}$ stretch region: a superposition of the asymmetric $\mathrm{C}=\mathrm{C}-\mathrm{C}=\mathrm{O}$ stretch with the $\mathrm{OH}$ in-plane bending at $1642 \mathrm{~cm}^{-1}$ and the $\mathrm{C}=\mathrm{O}$ stretching coupled to $\mathrm{OH}$ in-plane bending at $1624 \mathrm{~cm}^{-1}$. At low temperature, however, the $\mathrm{C}=\mathrm{O}$ band splits into three components [16], while two components can be seen in the d2-ACAC spectrum at all temperatures. These features have been attributed by Cohen and Weiss [16] to the fast interconversion of two energetically close forms of ACAC, presumably to TS2 and SYN. The harmonic analysis of Ref. [15] confirmed this assignment. In this frequency range, we located two normal modes at $1650 \mathrm{~cm}^{-1}$ and $1625 \mathrm{~cm}^{-1}$, both in very satisfactory agreement with room temperature data. In the TS2 rotamer, the two modes shift for only few wavenumbers to 1644 and $1628 \mathrm{~cm}^{-1}$. The difference between the SYN and TS2 frequencies is obviously too small to explain the three-maxima structure of the band. No other mode is close to this range, and combination transitions are expected to be much weaker. At low temperatures, contributions from the energetically less favorable TS1 rotamer can also be disregarded. Thus, the provided pieces of information are difficult to reconcile with previous assignments, and we leave the topic open for discussion.

Finally, we address the lower-frequency $\mathrm{OH}$ inplane bending mode coupled to the symmetric $\mathrm{C}=\mathrm{O}$ and $\mathrm{C}-\mathrm{C}=\mathrm{C}-\mathrm{O}$ stretch. The bending transition has not been observed in the gas phase due to the overlap with one of the keto bands. However, it has been observed in rare gas matrices at $1288 \mathrm{~cm}^{-1}$ [28] and after deconvolution of the liquid phase spectrum at $1302 \mathrm{~cm}^{-1}$. Our calculation yielded $1345 \mathrm{~cm}^{-1}$ for the SYN conformation and $1318 \mathrm{~cm}^{-1}$ for the TS2 conformation. Taking into account that transitions in rare gas matrices are shifted downward in comparison with the gas phase, we attributed the line to the TS2 conformer.

\section{Summary}

A quantum mechanical study of the enolic form of ACAC at the MP2 and B1LYP levels of theory is presented. Two conformers, SYN and TS2, are separated by an energy barrier of $0.25 \mathrm{kcal} \mathrm{mol}^{-1}$ at the MP2(FC)/6-311G $(d, p)$ and $0.13 \mathrm{kcal} \mathrm{mol}^{-1}$ at the B1LYP/6-311G $(d, p)$ level of theory. Their contribution to the vibrational spectrum is analyzed and the signature of both conformers is found in the spectrum. Specifically, the large difference in the $\mathrm{OH}$-stretch frequencies between the SYN and TS2 conformers finds agreement with the broadness of the experimental band. The frequency shift of the $v_{17}(\mathrm{OH}$-bend/symmetric $\mathrm{C}=\mathrm{O}, \mathrm{C}-\mathrm{C}=\mathrm{C}-\mathrm{O}$ stretch) fundamental can also be attributed to TS2. In contrast, the fast interconversion between the two forms cannot explain the three-maxima shape of the $\mathrm{C}=\mathrm{O}$ stretch band. On this issue, future investigation should go beyond the normal-mode analysis and should take into account the large-amplitude motion of the transferring proton [29].

\section{ACKNOWLEDGMENTS}

The authors are grateful to V. Mohaček-Grošev (RBI, Zagreb) for stimulating discussions. This work has been supported by the Croatian Ministry of Science and Technology under project 0098033, and by the Humboldt Foundation (to N.D.).

\section{References}

1. Hadži, D. Theoretical Treatments of Hydrogen Bonding; John Wiley \& Sons: Chichester, UK, 1997.

2. Emsley, J. Struct Bond 1984, 57, 147.

3. Bratos, S.; Leicknam, J.; Gallot, G.; Ratajczak, H. In Ultrafast Hydrogen Bonding Dynamics and Proton Transfer Processes in the Condensed Phase; Elsaesser, T.; Bakker, H., Eds.; Kluwer Academic: Dordrecht, the Netherlands, 2002; p 5.

4. Chamma, D.; Valcescu, A.; Blaise, P.; Henri-Rousseau, O. Chem Phys 2003, 293, 23

5. Belharaya, K.; Blaise, P.; Henri-Rousseau, O. Chem Phys 2003, 293, 9.

6. Došlić, N.; Kühn, O. Z Phys Chem 2003, 217, 1507.

7. Heyne, K.; Huse, N.; Nibbering, E.; Elsaesser, T. Chem Phys Lett 2003, 369, 591.

8. Heyne, K.; Huse, N.; Nibbering, E.; Elsaesser, T. Chem Phys Lett 2003, 382, 19.

9. Smith, Z.; Wilson, E. B.; Duerst, R. W. Spectrochim Acta A 1983, 39, 1117 .

10. Chiavassa, T.; Roubin, P.; Pizzala, L.; Verlaque, P.; Allouche, A.; Marinalli, F. J Phys Chem 1992, 96, 10659.

11. Ogoshi, H.; Nakamoto, K. J Chem Phys 1966, 45, 3113.

12. Tayyari, S. F.; Zeegers-Huyskens, T.; Wood, J. L. Spectrochim Acta A 1979, 35, 1289

13. Mavri, J.; Grdadolnik, J. J Phys Chem A 2001, 105, 2045.

14. Mavri, J.; Grdadolnik, J. J Phys Chem A 2001, 105, 2039.

15. Tayyari, S. F.; Milani-nejad, F. Spectrochim Acta A 2000, 56, 2679.

16. Cohen, B.; Weiss, S. J Phys Chem 1984, 88, 3159.

17. Adamo, C.; Barone, V. Chem Phys Lett 1997, 274, 242.

18. Frisch, M. J.; Trucks, G. W.; Schlegel, H. B.; Scuseria, G. E.; Robb,M.A.; Cheeseman, J. R.; Montgomery, Jr,J. A.; Vreven, T.; 
Kudin, K. N.; Burant, J. C.; Millam, J. M.; Iyengar, S. S.; Tomasi, J.; Barone, V.; Mennucci, B.; Cossi, M.; Scalmani, G.; Rega, N.; Petersson, G. A.; Nakatsuji, H.; Hada, M.; Ehara, M.; Toyota, K.; Fukuda, R.; Hasegawa, J.; Ishida, M.; Nakajima, T.; Honda, Y.; Kitao, O.; Nakai, H.; Klene, M.; Li, X.; Knox, J. E.; Hratchian, H. P.; Cross, J. B.; Adamo, C.; Jaramillo, J.; Gomperts, R.; Stratmann, R. E.; Yazyev, O.; Austin, A. J.; Cammi, R.; Pomelli, C.; Ochterski, J. W.; Ayala, P. Y.; Morokuma, K.; Voth, G. A.; Salvador, P.; Dannenberg, J. J.; Zakrzewski, V. G.; Dapprich, S.; Daniels, A. D.; Strain, M. C.; Farkas, O.; Malick, D. K.; Rabuck, A. D.; Raghavachari, K.; Foresman, J. B.; Ortiz, J. V.; Cui, Q.; Baboul, A. G.; Clifford, S.; Cioslowski, J.; Stefanov, B. B.; Liu, G.; Liashenko, A.; Piskorz, P.; Komaromi, I.; Martin, R. L.; Fox, D. J.; Keith, T.; Al-Laham, M. A.; Peng, C. Y.; Nanayakkara, A.; Challacombe, M.; Gill, P. M. W.; Johnson, B.; Chen, W.; Wong, M. W.; Gonzalez, C.; Pople, J. A. Gaussian 03; Revision B.05; Gaussian: Pittsburgh, PA, 2003.

19. Schmidt, M. W.; Baldridge, K. K.; Boatz, J. A.; Elbert, S. T.; Gordon, M. S.; Jensen, J. H.; Koseki, S.; Matsunaga, N.; Nguyen, K. A.; Su, S.; Windus, T. L. J Comput Chem 1993, $14,1347$.

20. Barone, V.; Manichino, C. J Mol Struct 1995, 330, 365.

21. Barone, V.; J Chem Phys 2005, 122, 014108.

22. Folkendt, M.; Weiss-Lopez, B.; Chauvrel, J.; True, N. S. J Phys Chem 1985, 89, 3347.

23. Sliznev, V.; Lapshina, S.; Girichev, G. J Struct Chem 2002, 43, 47.
24. Matanović, I.; Došlić, N.; Mihalić, Z. Chem Phys 2004, 306, 201.

25. Johnson, M.; Jones, N.; Geis, A.; Horsewill, A.; Trommsdorff, H. P. J Chem Phys 2002, 116, 5694.

26. Frisch, M. J.; Trucks, G. W.; Schlegel, H. B.; Scuseria, G. E.; Robb, M. A.; Cheeseman, J. R.; Zakrzewski, V. G.; Montgomery, Jr, J. A.; Stratmann, R. E.; Burant, J. C.; Dapprich, S.; Millam, J. M.; Daniels, A. D.; Kudin, K. N.; Strain, M. C.; Farkas, O.; Tomasi, J.; Barone, V.; Cossi, M.; Cammi, R.; Mennucci, B.; Pomelli, C.; Adamo, C.; Clifford, S.; Ochterski, J.; Petersson, G. A.; Ayala, P. Y.; Cui, Q.; Morokuma, K.; Malick, D. K.; Rabuck, A. D.; Raghavachari, K.; Foresman, J. B.; Cioslowski, J.; Ortiz, J. V.; Stefanov, B. B.; Liu, G.; Liashenko, A.; Piskorz, P.; Komaromi, I.; Gomperts, R.; Martin, R. L.; Fox, D. J.; Keith, T.; Al-Laham, M. A.; Peng, C. Y.; Nanayakkara, A.; Gonzalez, C.; Challacombe, M.; Gill, P. M. W.; Johnson, B.; Chen, W.; Wong, M. W.; Andres, J. L.; Gonzalez, C.; Head-Gordon, M.; Replogle, E. S.; Pople, J. A. Gaussian 98; Revision A.11; Gaussian: Pittsburgh, PA, 2001.

27. Martin, J. M. L.; Lee, T. J.; Taylor, P. R.; Francois, J. J Chem Phys 1995, 103, 2589.

28. Chiavassa, T.; Verlaque, P.; Pizzala, L.; Roubin, P. Spectrochim Acta A 1994, 50, 343.

29. Matanović, I.; Došlić, N. J Phys Chem 2005, 109, 4185. 